\title{
MộT SỐ KẾT QUẢ BƯớC ĐẦU NGHIÊN CỬU VỀ RÙ̉NG NGẬP MẶN NAM TRUNG Bộ
}

\author{
Đỗ Quý Mạnh', Nguyễn Quốc Huy ${ }^{1}$, Lê Văn Tuất ${ }^{1}$
}

Tóm tắt: Rìng ngập mặn (RNM) khu vục Nam Trung Bộ là hệ sinh thái đặc trung, đa chức năng cho vùng duyên hải, RNM khu vưc này có vai trò đặc biệt quan trong trong việc bảo vệ đất cứa sông, vùng đầm, vịnh, chống xói mòn, sạt lở, đặc biệt bảo vệ cuộc sống và sinh kế của công đồng dân cur. Khu vưc nghiên cứu có độ mặn nước biển cao, thwờng xuyên bị ảnh hưởng bởi bão gió mạnh hàng năm là nhũng yếu tố khó khăn cho việc phục hồi RNM. Nghiên cưu đã áp dụng phưong pháp tổng hợ, điều tra thực địa được diện tích rùng và đất ngập mặn là 824,59 ha, trong đó diện tích diện tích có RNM là 359,06 ha. Nghiên cúu đã xác định được 21 loài thực vật, thuộc 12 chi và 10 ho thực vật. Đã ghi nhận thêm vùng phân bố mới của loài Cóc đỏ (Lumnitzera littorea (Jack) Voigt) là loài quý hiếm ở mức VU - múc sẽ nguy cấp trong Sách Đỏ Việt Nam (2007) tại Ninh Thuận. Buớc đầu phát hiện một loài Giáp xác chân đều Sphaeroma terebrans Bate (1866), thuộc ho Sphaeromatideae, bộ Chân đều (Isopoda) hại cây ngập mặn Bần trắng (Sonneratia alba Smith) trên 3 tuổi gây hại RNM ở tỉnh Bình Định. Bước đầu đề xuất giải pháp trồng RNM phù hợp với đặc điểm lập địa bằng giải pháp kỹ thuật lâm sinh.

Từ khóa: Hiện trạng rùng, RNM, Nam Trung Bộ.

Ban Biên tập nhận bài: 12/7/2019 Ngày phản biện xong: 20/8/2019 Ngày đăng bài: 25/09/2019

\section{Mở đầu}

Việt Nam có chiều dài bờ biển trên $3.260 \mathrm{~km}$, diện tích RNM trên 145.000 ha (năm 2018) trải dài 28 tỉnh, thành phố ven biển. RNM khu vực Nam Trung Bộ là một hệ sinh thái đặc biệt cho dải đất miền Trung Việt Nam. Đây là một trong những vùng kinh tế trọng điểm của cả nước, có tiềm năng phát triển các ngành nghề du lịch, khai thác và nuôi trồng thủy sản, dịch vụ hàng hải và ngành công nghiệp chế xuất. Tuy nhiên, các hiện tượng thiên tai bão lũ thường gây thiệt hại nặng nề cho khu vực. Đặc biệt, do điều kiện địa hình dốc, lũ lụt diễn ra nhanh chóng và thất thường. Trong bối cảnh $\mathrm{BĐKH}$, tần suất của các hiện tượng thời tiết cực đoan như thay đổi lượng mưa, nhiệt độ... diễn ra ngày càng phức tạp thì khu vực này sẽ còn chịu nhiều ảnh hưởng nặng nề, nhất là vùng duyên hải ven biển. Đặc biệt sự tác động ảnh hưởng đến cây ngập mặn tồn tại và phát triển.

Các nghiên cứu hiện nay về RNM tại khu vực

${ }^{1}$ Viện Sinh thái và Bảo vệ công trình

Email:doquymanh@gmail.com
Nam Trung Bộ còn tản mạn, rất ít tài liệu nghiên cứu về phân bố các loài thực vật, đa dạng sinh học. Chưa có nghiên cứu đầy đủ về điều kiện tự nhiên, hiện trạng RNM và tầm quan trọng của RNM đối với khu vực Nam Trung Bộ. Theo số liệu diện tích rừng và đất ngập mặn năm 2016 và kết quả điều tra, theo dõi diễn biến rừng và công bố hiện trạng rừng toàn quốc của Bộ Nông nghiệp và Phát triển nông thôn, năm 2017 dao động trên 200 ha (năm 2016 trên 260 ha [1], năm 2017 là 214 ha [2]). Tuy nhiên, theo kết quả điều tra, khảo sát thực địa của Viện Sinh thái và Bảo vệ công trình thì diện tích RNM tại khu vực trên 360 ha. Phân bố RNM tập trung ở vùng đầm, vùng cửa sông nên bị thay đổi mạnh theo thời gian và không gian, phương thức sử dụng, sự biến động lớn về diện tích và chất lượng. Vì vậy, việc đánh giá hiện trạng RNM khu vực Nam Trung Bộ là cần thiết để đề xuất các hướng tác động tích cực vào RNM, đặc biệt đề xuất giải pháp chọn loài cây trồng RNM, xây dựng bản đồ lập địa ngập mặn, giải pháp trồng RNM trên điều 
kiện lập địa khó khăn và rất khó khăn trong giai đoạn hiện nay.

\section{2. Đối tượng và phương pháp nghiên cứu}

2.1. Giới thiệu khu vục nghiên cúu

Rừng ngập mặn và đất ngập mặn ở các tỉnh ven biển khu vực Nam Trung Bộ phân bố rải rác tại các vùng cửa sông và chủ yếu tập trung ở khu vực các đầm, vịnh...bao gồm các tỉnh Quảng Nam, Quảng Ngãi, Bình Định, Phú Yên, Khánh Hòa, Ninh Thuận và Bình Thuận (Hình 1) với diện tích rừng và đất ngập mặn trên 824,59 ha. Thành phần loài thực vật đơn giản, chủ yếu là một số loài Mắm trắng (Avicennia alba), Mắm biển (Avicennia marina), Đước đôi (Rhizophora apiculata), Bần chua (Sonneratia caseolaris) và Bần trắng (Sonneratia alba),...Với đặc trưng địa hình dốc lớn, bị chia cắt nhiều, hàm lượng phù sa ít, độ mặn cao,... đã làm cho RNM khu vực Nam Trung Bộ kém phát triển hơn các khu vực khác. Hiện nay, biến đổi khí hậu (BĐKH) đã và đang ảnh hưởng rất lớn đến quá trình phát sinh, sinh trưởng và phát triển của rừng ngập mặn. Hiện tượng nước biển dâng kèm theo đó là thời gian ngập bãi sẽ tăng lên làm cho cây ngập mặn ngày một khó thích nghi hơn với điều kiện bãi bồi, đồng thời theo đó thời gian ngập nhiều hơn những cây ngập mặn giáp biển cũng sinh trưởng chậm hơn. Cùng theo nước biển dâng là các hiện tượng gió bão, triều cường cũng tăng lên, mạnh mẽ hơn, công phá bờ biển nhiều hơn góp phần vào làm mất bãi sinh trưởng của cây ngập mặn...

Một số đặc điểm về điều kiện tự nhiên liên quan đến rừng ngập mặn

Khu vực ven biển Nam Trung Bộ có tổng chiều dài trên $1.200 \mathrm{~km}$, là nơi thường xuyên phải gánh chịu nhiều thiên tai, gió bão, lũ lụt, sóng lớn, triều cường; đặc biệt là hiện tượng nước biển dâng do tác động của BĐKH. Khu vực có đặc trưng khí hậu gió mùa mang tính chất cận xích đạo; chế độ thủy triều thuộc dạng chế độ nhật triều không đều. Độ cao thủy triều trong kỳ nước cường trung bình $1,2-2,0 \mathrm{~m}$ và tăng dần về phía nam.

Khu vực nghiên cứu có địa hình ven biển dốc, độ mặn nước biển cao, ít thích hợp cho các loài cây ngập mặn, đồng thời khu vực thường xuyên chịu tác động mạnh của gió, sóng biển, triều cường, bão lớn,... là những yếu tố hạn chế, gây trở ngại cho công tác khôi phục và phát triển RNM. Mặt khác, các địa điểm nghiên cứu phục hồi RNM nằm trong khu vực đi lại khó khăn, chi phí vận chuyển lớn, lực lượng lao động ít,... nên công tác trồng, quản lý bảo vệ rừng cũng như triển khai các hoạt động sản xuất lâm nghiệp trên địa bàn gặp nhiều khó khăn.

Theo Kịch bản biến đổi khí hậu của Bộ Tài nguyên và Môi trường (2016) [3] cho khu vực ven biển Nam Trung Bộ trong thế kỷ 21 có thể được tóm tắt như sau:

Về nhiệt độ: Khu vực Nam Trung Bộ, cuối thế kỷ 21 , nhiệt độ tăng $1,6^{\circ} \mathrm{C}, 2-3^{\circ} \mathrm{C}, 2,5-3,7^{\circ} \mathrm{C}$ tưng ứng theo kịch bản phát thải thấp, trung bình và cao.

Về lượng mưa: Theo các kịch bản phát thải thấp, trung bình và cao thì đến cuối thế kỷ 21 , lượng mưa năm tăng phổ biến khoảng trên $6 \%$, 2-7\%, 2-10\% ở khu vực Nam Trung Bộ.

Về mực nước biển dâng: Theo kịch bản phát thải thấp, trung bình, cao thì mực nước biển dâng tương ứng lần là trong khoảng $49-64 \mathrm{~cm}, 57-$ $73 \mathrm{~cm}$ và $78-95 \mathrm{~cm}$.

Nếu mực nước biển dâng $1 \mathrm{~m}$, sẽ có khoảng $39 \%$ diện tích đồng bằng sông Cửu Long, trên $10 \%$ diện tích đồng bằng sông Hồng và Quảng Ninh, trên 2,5\% diện tích thuộc các tỉnh ven biển miền Trung và trên $20 \%$ diện tích thành phố Hồ Chí Minh có nguy cơ bị ngập; gần 35\% dân số thuộc các tỉnh vùng đồng bằng sông Cửu Long, trên $9 \%$ dân số vùng đồng bằng sông Hồng và Quảng Ninh, gần $9 \%$ dân số các tỉnh ven biển miền Trung và khoảng 7\% dân số thành phố Hồ Chí Minh bị ảnh hưởng trực tiếp, trên $4 \%$ hệ thống đường sắt, trên $9 \%$ hệ thống quốc lộ và khoảng 12\% hệ thống tỉnh lộ của Việt Nam sẽ bị ảnh hưởng.

Chính vì vậy, khu vực duyên hải Nam Trung Bộ cũng sẽ bị chịu ảnh hưởng nặng nề của nước biển dâng. Do đó, việc lựa chọn loài cây phù hợp với sự thay đổi của điều kiện tự nhiên như: nhiệt độ, lượng mưa, sự thay đổi mực nước biển,..là vấn đề cần được nghiên cứu và có giải pháp phù hợp đối với khu vực Nam Trung Bộ. 


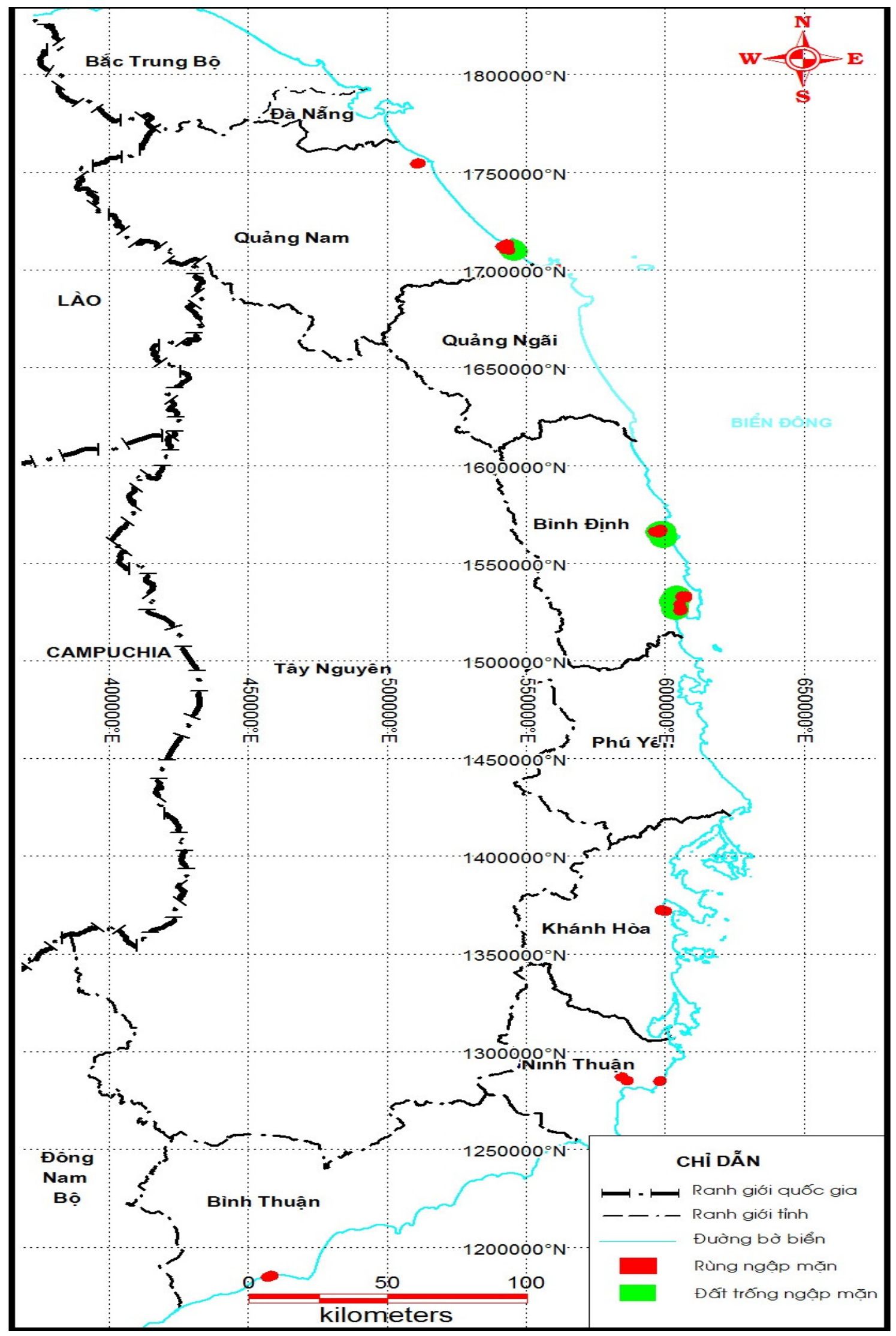

Hình 1. Phân bố rùng và đất ngập mặn tại khu vục Nam Trung Bộ 
- Phương pháp kế thừa: Kế thừa số liệu, tài liệu, các kết quả nghiên cứu liên quan về biến đổi khí hậu, nước biển dâng và hiện trạng RNM;

- Phương pháp điều tra khảo sát RNM: Lập tuyến và điều tra các chỉ tiêu lâm lập theo phương pháp ô tiêu chuẩn (OTC) điển hình và tạm thời được sử dụng trong lâm nghiệp. Lập 35 tuyến điển hình cho các dạng điều tra; Lập 63 OTC cho các trạng thái rừng tự nhiên, rừng trồng. Diện tích mỗi OTC là $300 \mathrm{~m}^{2}$ cho rừng trồng và $500 \mathrm{~m}^{2}$ cho rừng tự nhiên.

Thu thập số liệu trên các OTC:

Trên OTC thu thập các chỉ tiêu: Tên loài, đo đếm các chỉ tiêu sinh trưởng về đường kính gốc $\left(\mathrm{D}_{0}, \mathrm{~cm}\right)$ bằng thước dây đo vanh, có độ chính xác đến $0,1 \mathrm{~cm}$; chiều cao vút ngọn $(\mathrm{Hvn}, \mathrm{m})$ bằng thước sào có khắc vạch, có độ chính xác đến $\mathrm{cm}$ và đường kính tán $(\mathrm{Dt}, \mathrm{m})$ bằng thước dây, có độ chính xác đến cm, đo 2 hướng vuông góc, chế độ ngập triều (kế thừa số liệu quan trắc tại địa phương, kết hợp kiểm chứng, đo tính ngoài thực địa).

Phẩm chất cây, được đánh giá thông qua các chỉ tiêu hình thái theo 3 cấp (Tốt, trung bình và xấu). Trong đó: Cây tốt (A) là những cây sinh trưởng khỏe mạnh, cân đối; tán đều, không bị sâu bệnh, cây trung bình (B) là những cây có thân không được cân đối như loại $\mathrm{A}$, sinh trưởng trung bình, cây xấu $(\mathrm{C})$ là những cây sâu bệnh, tán lệch, ít có triển vọng, sinh trưởng kém.

- Phương pháp phân chia lập địa: Theo tài liệu "Ưng dụng lập địa trong Lâm nghiệp,, của tác giả Ngô Đình Quế và Nguyễn Xuân Quát, 2012 [4]. Phương pháp sử dụng các yếu tố cấu thành lập địa như loại đất ngập mặn, độ mặn nước biển, thời gian phơi bãi, độ thành thục của đất, tỷ lệ phần trăm hạt cát, cao trình đất ngập mặn, hiện trạng rừng và đất ngập mặn trên cơ sở các chỉ tiêu, giá trị, thang điểm để phân loại ra các mức độ khác nhau cho từng yếu tố. Tổ hợp 7 yếu tố trên sẽ xác định được nhóm dạng lập địa đất ngập mặn khu vực ven biển Nam Trung Bộ.

- Địa điểm và phạm vi nghiên cứu: Trên cơ sở hiện trạng diện tích RNM, đất RNM của khu vực các tỉnh ven biển Nam Trung Bộ. Tuy nhiên, qua khảo sát sơ bộ thành phố Đà Nẵng không có RNM và đất ngập mặn nên số liệu được thống kê tại 7 tỉnh (Quảng Nam, Quảng Ngãi, Bình Định, Phú Yên, Khánh Hòa, Ninh Thuận và Bình Thuận).

- Phương pháp xử lý số liệu: Sử dụng các phương pháp thống kê toán học trong sinh học với sự hỗ trợ của các phần mềm như SPSS, R, EXCEL, Mapinfor, Microsition để xử lý số liệu.

\section{Kết quả nghiên cứu và thảo luận}

\subsection{Diện tích rùng và đất ngập mặn $k h u$} vục Nam Trung Bộ

Nghiên cứu đã kế thừa các kết quả về kiểm kê rừng năm 2016, theo dõi diễn biến rừng năm 2017 của Bộ Nông nghiệp và Phát triển nông thôn. Tuy nhiên, trong quá trình điều tra khảo sát thực địa năm 2017 và 2018 đã thống kê được phân bố, diện tích rừng và đất ngập mặn như sau.

Kết quả nghiên cứu cho thấy: Diện tích đất quy hoạch cho trồng RNM khu vực Nam Trung Bộ là 824,59 ha. Trong đó, diện tích đất trống ngập mặn là 465,53 ha, diện tích RNM là 359,06 ha. So sánh với 2 nguồn số khác bảng 2 trên thì có sự chênh lệch nhau đáng kể. Điều này có thể lý giải do diện tích RNM 2 tỉnh Ninh Thuận và Quảng Ngãi chưa được cập nhật theo dõi diễn biến RNM toàn quốc hàng năm.

Cơ cấu đất ngập mặn của khu vực rất đơn giản, diện tích đất trống còn ít, lại tập trung ở các khu vực ngập triều sâu, sóng lớn, dải đất hẹp,...thuộc dạng lập địa rất khó khăn và khó khăn. Tập trung diện tích đất trống chủ yếu ở các tỉnh như Bình Định trên 448 ha, Quảng Nam trên 12 ha và Ninh Thuận 5 ha 
Bảng 1. Diện tích rì̀ng và đất ngập mặn các tỉnh ven biển Nam Trung Bộ năm 2018 (ĐVT: ha)

\begin{tabular}{|c|c|c|c|c|c|c|c|c|}
\hline \multirow{2}{*}{ STT } & \multirow{2}{*}{ Tỉnh } & \multicolumn{3}{|c|}{$\begin{array}{c}\text { Diện tích rừng và dất ngập } \\
\text { mặn theo nguồn kiểm kê } \\
\text { rừng } 2016 \text { [1] }\end{array}$} & \multirow{2}{*}{$\begin{array}{c}\text { Diện tích } \\
\text { rừng theo } \\
\text { nguồn của } \\
\text { Cục Kiểm } \\
\text { lâm } 2017 \\
{[2]}\end{array}$} & \multicolumn{3}{|c|}{$\begin{array}{c}\text { Kết quả điều tra khảo sát } \\
\text { thực địa của đề tài }\end{array}$} \\
\hline & & $\begin{array}{c}\text { Tổng } \\
\text { DT đất } \\
\text { quy } \\
\text { hoạch }\end{array}$ & $\begin{array}{l}\text { Đất } \\
\text { trống } \\
\text { ngập } \\
\text { mận }\end{array}$ & $\begin{array}{l}\text { Diện } \\
\text { tích } \\
\text { RNM }\end{array}$ & & $\begin{array}{c}\text { Tổng diện } \\
\text { tích đất quy } \\
\text { hoạch trồng } \\
\text { RNM }\end{array}$ & $\begin{array}{l}\text { Đất } \\
\text { trống } \\
\text { ngập } \\
\text { mặn }\end{array}$ & $\begin{array}{l}\text { Diện } \\
\text { tích } \\
\text { RNM }\end{array}$ \\
\hline 1 & Tp Đà Nẵng & 0,00 & 0,00 & 0,00 & 0,00 & 0 & 0 & 0 \\
\hline 2 & Quảng Nam & 88,82 & 0,00 & 88,82 & 46,32 & 60,22 & 12,45 & 47,77 \\
\hline 3 & Quảng Ngãi & 49,88 & 6,20 & 43,68 & 2,78 & 95,42 & 0 & 95,42 \\
\hline 4 & Bình Định & 547,46 & 450,00 & 97,46 & 92,24 & 511,01 & 448,08 & 62,93 \\
\hline 5 & Phú Yên & 0,00 & 0,00 & 0,00 & 0,00 & 0 & 0 & 0 \\
\hline 6 & Khánh Hòa & 11,96 & 0,00 & 11,96 & 60,04 & 56,47 & 0 & 56,47 \\
\hline 7 & Ninh Thuận & 0,00 & 0,00 & 0,00 & 0,00 & 67,81 & 5 & 62,81 \\
\hline 8 & Bình Thuận & 27,05 & 8,49 & 18,56 & 12,63 & 33,66 & 0 & 33,66 \\
\hline & Tổng cộng & 725,17 & 464,69 & 260,48 & 214,01 & 824,59 & 465,53 & 359,06 \\
\hline
\end{tabular}

\subsection{Thành phần loài cây ngập mặn khu vụcc Nam Trung Bộ}

Trong quá trình điều tra về thành phần loài cây ngập mặn trong khu vực ven biển Nam Trung Bộ, bước đầu đã xác định được 21 loài thuộc 12 chi và 10 họ thực vật (Bảng 2).

Kết quả số lượng loài thực vật ngập mặn tại khu vực có sai khác với các kết quả của các tác giả khác như Nguyễn Xuân Hòa, 2010 chiếm 21/40 loài cây ngập mặn [5]. So sánh với kết quả của Hoàng Văn Thơi, Trần Đức Thành, Kiều Mạnh Hà, 2012 chiếm 21/29 loài cây ngập mặn [6]. Số lượng các loài cây ngập mặn thay đổi theo vùng khảo sát, có sự biến động lớn. Các tỉnh Bình Định, Bình Thuận, Khánh Hòa, Quảng Nam có số lượng trên 15 loài thực vật ngập mặn bắt gặp. Trong khi đó thành phố Đà Nẵng, tỉnh Phú Yên chỉ bắt gặp được 4 đến 5 loài thực vật ngập mặn. Điều này có thể nhận thấy đa dạng loài cây ngập mặn ở những vùng này rất nghèo nàn. So sánh với các điều tra trước của các tác giả Phan Nguyên Hồng, Hoàng Thị Sản năm 1984 [7] nhận thấy vùng này có trên 37 loài cây ngập mặn thực thụ tham gia. Có thể do chuyển đổi mục đích sử dụng rừng sang nuôi trồng thủy sản, ảnh hưởng của các điều kiện tự nhiên bất lợi như nước biển dâng, triều cường, bão, gió lớn...đã làm suy giảm số lượng loài thực vật ngập mặn trong khu vực. Tuy nhiên, có những loài như Đước đôi, Mắm biển, Cóc trắng,...bắt gặp ở hầu hết các khu vực điều tra. Điều này cho thấy biên độ sinh thái của 3 loài này khá rộng, sinh trưởng trên nhiều dạng lập địa khác nhau. Kết quả cũng cho nhận định việc chọn loài Đước đôi (Rhizophora apiculata Blume) và Mắm biển (Avicennia marina (Forssk.) Vierh) để phục hồi và phát triển RNM khu vực Nam Trung Bộ là phù hợp.

Ghi nhận thêm vùng phân bố mới của loài Cóc đỏ (Lumnitzera littorea (Jack) Voigt) là loài quý hiếm ở mức VU - mức sẽ nguy cấp trong Sách Đỏ Việt Nam (2007) tại Ninh Thuận so với trước đây (Thừa Thiên Huế, Khánh Hòa (Cam Ranh), Bà Rịa-Vũng Tàu (Côn Đảo), Kiên Giang (Phú Quốc), Bạc Liêu). 


\section{BÀI BÁO KHOA HỌC}

Bảng 2. Danh lục thực vật khu vục ven biển Nam Trung Bộ

\begin{tabular}{|c|c|c|c|c|c|c|c|c|c|c|c|}
\hline \multicolumn{2}{|c|}{ STT } & \multirow[b]{2}{*}{ Tên khoa học } & \multirow{2}{*}{$\begin{array}{l}\text { Tên Việt } \\
\text { Nam }\end{array}$} & \multicolumn{8}{|c|}{ Khu vực khảo sát } \\
\hline Họ & Loài & & & $\begin{array}{l}\text { Bình } \\
\text { Thuận }\end{array}$ & $\begin{array}{l}\text { Ninh } \\
\text { Thuận }\end{array}$ & $\begin{array}{l}\text { Khánh } \\
\text { Hòa }\end{array}$ & Phú Yên & $\begin{array}{l}\text { Bình } \\
\text { Định }\end{array}$ & $\begin{array}{l}\text { Quảng } \\
\text { Ngãi }\end{array}$ & $\begin{array}{l}\text { Quảng } \\
\text { Nam }\end{array}$ & $\begin{array}{l}\text { Tp Đà } \\
\text { Nã̃ng }\end{array}$ \\
\hline & & MAGNOLIOPHYTA & $\begin{array}{l}\text { Ngành Ngọc } \\
\text { lan }\end{array}$ & & & & & & & & \\
\hline & & MAGNOLIOSIDA & Lóp Ngoc lan & & & & & & & & \\
\hline 1 & & AIZOACEAE & $\begin{array}{l}\text { Họ Rau đắng } \\
\text { đất }\end{array}$ & & & & & & & & \\
\hline & 1 & Sesuvium portulacustrum $\mathrm{L}$. & Sam biển & + & + & + & + & + & + & + & + \\
\hline 2 & & AVICENNIACEAE & Họ Mắm & & & & & & & & \\
\hline & 2 & Avicennia alba Blume & Mắm trắng & ++ & +++ & +++ & 0 & + & 0 & ++ & 0 \\
\hline & 3 & Avicennia marina (Forssk.) Vierh. & Mắm biển & ++ & +++ & +++ & 0 & +++ & + & +++ & 0 \\
\hline & 4 & Avicennia officinalis $\mathrm{L}$. & Mắm đen & 0 & ++ & ++ & 0 & + & & & 0 \\
\hline 3 & & COMBRETACEAE & Họ Bàng & & & & & & & & \\
\hline & 5 & Lumnitzera racemosa Willd. & Cóc trắng & +++ & +++ & +++ & 0 & + & +++ & + & 0 \\
\hline & 6 & Lumnitzera littorea (Jack) Voigt & Cóc đỏ & 0 & + & 0 & 0 & 0 & 0 & 0 & 0 \\
\hline 4 & & EUPHORBIACEAE & Họ Thầu dầu & & & & & & & & \\
\hline & 7 & Excoecaria agallocha $\mathrm{L}$. & Giá & + & + & + & + & + & 0 & + & 0 \\
\hline 5 & & MYRSINACEAE & Họ Đơn nem & & & & & & & & \\
\hline & 8 & $\begin{array}{l}\text { Aegiceras.corniculatum (L.) } \\
\text { Blanco }\end{array}$ & Sú cong & + & 0 & ++ & 0 & +++ & 0 & 0 & 0 \\
\hline 6 & & RHIZOPHORACEAE & Họ Đước & & & & & & & & \\
\hline & 9 & Bruguiera cylindrica (L.) Blume & Vẹt trụ & 0 & 0 & 0 & 0 & ++ & 0 & 0 & 0 \\
\hline & 10 & Bruguiera gymnorrhiza (L.) Lam. & Vẹt bông đỏ & + & + & + & 0 & ++ & + & + & 0 \\
\hline & 11 & $\begin{array}{l}\text { Ceriops decandra (Griff.) Ding } \\
\text { Hou }\end{array}$ & Dà quánh & 0 & 0 & 0 & 0 & ++ & 0 & 0 & 0 \\
\hline & 12 & Ceriops tagal (Perr) C. B. Robins. & Dà vôi & +++ & 0 & + & 0 & + & 0 & 0 & 0 \\
\hline & 13 & Rhizophora apiculata Blume & Đước đôi & +++ & +++ & +++ & 0 & +++ & +++ & +++ & 0 \\
\hline & 14 & Rhizophora mucronata Lam. & Đưng & ++ & + & + & + & + & 0 & 0 & 0 \\
\hline 7 & 15 & $\begin{array}{l}\text { Rhizophora stylosa Griff. } \\
\text { RUBIACEAE }\end{array}$ & $\begin{array}{l}\text { Đâng } \\
\text { Ho Cà phê }\end{array}$ & + & +++ & +++ & + & ++ & 0 & 0 & 0 \\
\hline & 16 & $\begin{array}{l}\text { Scyphiphora hydrophyllaceae } \\
\text { Gaertn. }\end{array}$ & Côi & + & + & + & 0 & 0 & 0 & 0 & 0 \\
\hline 8 & & SONNERATIACEAE & Họ Bần & & & & & & & & \\
\hline & 17 & Sonneretia caseolaris (L.) Engl & Bần chua & 0 & 0 & + & 0 & + & + & + & 0 \\
\hline & 18 & Sonneretia alba $\mathrm{Sm}$. & Bần trắng & + & + & + & 0 & ++ & 0 & 0 & 0 \\
\hline 9 & & STERCULIACEAE & Họ Trôm & & & & & & & & \\
\hline & 19 & $\begin{array}{l}\text { Heritiera littoralis Aiton } \\
\text { LILIOPSIDA }\end{array}$ & $\begin{array}{l}\text { Cui biển } \\
\text { Lóp Hành }\end{array}$ & + & + & 0 & 0 & 0 & 0 & 0 & 0 \\
\hline 10 & & ARECACEAE & $\mathrm{Họ} \mathrm{Cau}$ & & & & & & & & \\
\hline & 20 & Phoenix paludosa Roxb. & Chà là & 0 & 0 & 0 & 0 & + & 0 & 0 & 0 \\
\hline & 21 & Nypa fruticans Wurmb & Dừa nước & 0 & 0 & 0 & + & + & + & +++ & 0 \\
\hline
\end{tabular}

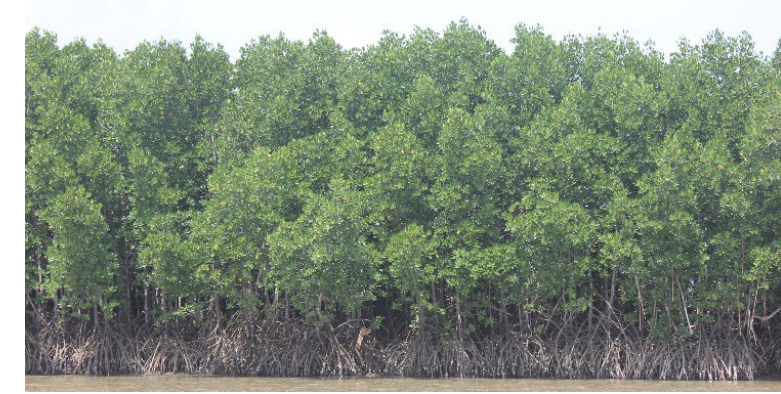

Hình 2. Rùng ngập mặn Đước đôi (Rhizophora apiculata) tại Bình Định

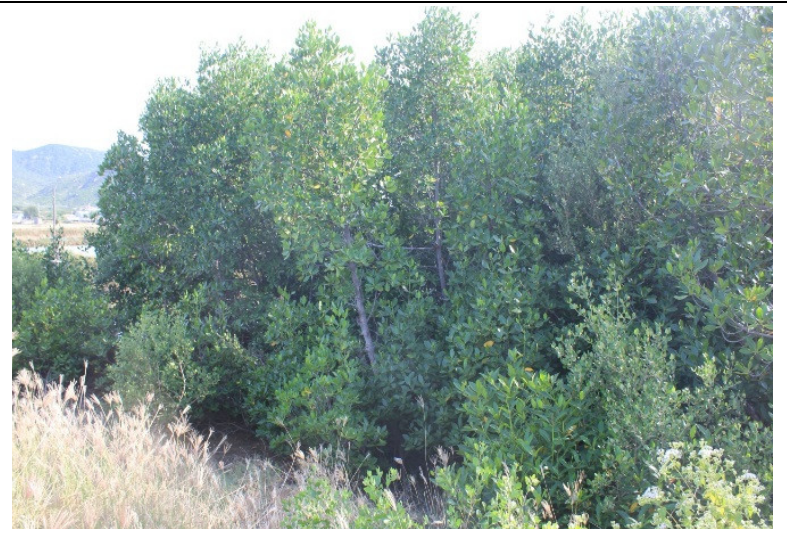

Hình 3. Khu vưc rùng ngập mặn tỉnh Ninh Thuận, nơ có phân bố cây Cóc đỏ (Lumnitzera littorea) loài có tên trong Sách Đỏ Việt Nam 2007 


\subsection{Sinh trưởng của RNM ở một số khu vục nghiên cứu}

Trong quá quá trình điều tra thu thập các chỉ tiêu lâm học về hình thái của các cây ngập mặn tại 40 ô tiêu chuẩn tạm thời, điển hình cho một số trạng thái RNM trong khu vực, chúng tôi thống kê được kết quả sau.

Bảng 3. Một số chỉ tiêu lâm học RNM tại khu vực nghiên cứu

\begin{tabular}{|c|c|c|c|c|c|c|c|c|c|}
\hline \multirow[t]{2}{*}{ STT } & \multirow[t]{2}{*}{ Tỉnh } & \multirow{2}{*}{$\begin{array}{l}\text { Loại } \\
\text { rừng }\end{array}$} & \multirow{2}{*}{ Loài cây } & \multirow{2}{*}{$\begin{array}{l}\text { Tuồi } \\
\text { rừng } \\
\text { (năm) }\end{array}$} & \multirow{2}{*}{$\begin{array}{l}\text { Mật độ } \\
\text { (cây/ha) }\end{array}$} & \multirow{2}{*}{$\begin{array}{l}\text { Doo } \\
(\mathrm{cm})\end{array}$} & \multirow{2}{*}{$\begin{array}{l}\text { Hvn } \\
(\mathrm{m})\end{array}$} & \multicolumn{2}{|c|}{$\begin{array}{c}\mathrm{Dt} \\
(\mathrm{cm})\end{array}$} \\
\hline & & & & & & & & ĐT & NB \\
\hline 1 & Quảng Nam & RT & Mắm biển & 12 & 4600 & 14,72 & 4,47 & 4,71 & 4,78 \\
\hline 2 & Quảng Ngãi & RT & Cóc trắng & 8 & 3100 & 12,68 & 6,92 & 4,17 & 4,19 \\
\hline 3 & Bình Định & RT & Bần trắng & 16 & 2300 & 15,34 & 3,15 & 3,24 & 3,15 \\
\hline 4 & Khánh Hòa & $\mathrm{RT}$ & Đước đôi & 15 & 4200 & 17,43 & 9,12 & 6,00 & 5,94 \\
\hline 5 & Ninh Thuận & RT & Mắm biển & 7 & 3900 & 9,00 & 3,49 & 3,01 & 2,98 \\
\hline 6 & Bình Thuận & RTN & $\begin{array}{l}\text { Cóc trắng, } \\
\text { Đước đôi }\end{array}$ & 19 & 3700 & 6,06 & 5,95 & 3,40 & 3,36 \\
\hline
\end{tabular}

Ghi chú: RT: Rùng trồng, RTN: Rùng tư nhiên, Doo: Đuòng kính gốc cây, Hvn: Chiều cao vút ngon, Đ-T: đường kính tán Đông - Tây và Nam - Bắc.

Kết quả nghiên cứu chỉ ra trong mối tương quan giữa tuổi cây và các chỉ số về hình thái cây như sinh trưởng về chiều cao, đường kính gốc, đường kính tán của các loài Mắm biển (Avicennia marina (Forssk.) Vierh), Cóc trắng (Lumnitzera racemosa Willd) và Đước đôi (Rhizophora apiculata Blume) trong khu vực thuộc loại sinh trưởng trung bình và kém, điều này có thể được lý giải đặc điểm đất về lý hóa tính trong khu vực thuộc loại đất nghèo dinh dưỡng, lượng phù sa bồi tụ hàng năm không được giữ lại, đất có hàm lượng dinh dưỡng các chất như đạm, lân, kali thuộc loại nghèo. Do vậy cần có giải pháp để cải tạo đất, giữ lượng phù sa bồi tụ hàng năm, chống rửa trôi và xói mòn bề mặt thể nền. Với hiện trạng các chỉ tiêu lâm học trên chúng tôi xác định chất lượng rừng trồng và rừng tự nhiên tại khu vực nghiên cứu thuộc loại rừng nghèo cần được cải tạo bằng các giải pháp phục hồi rừng, trồng bổ sung một số loài cây bản địa tại địa phương.

Trong quá trình điều tra sinh trưởng của cây ngập mặn, một diện tích RNM ở tỉnh Quảng Ngãi và Bình Định đã và đang bị một số loài động vật gây hại, làm suy giảm và gây chết RNM hàng chục ha như khu vực đầm Thị Nại, tỉnh Bình Định. Qua việc thu thập và bước đầu xác định được loài sinh vật gây hại rừng Bần trắng (Sonneratia alba Smith) trên 3 năm tuổi là một loài Giáp xác chân đều thuộc lớp mai mềm có tên khoa học là Sphaeroma terebrans Bate, 1866, thuộc họ Sphaeromatideae, bộ Chân đều Isopoda. Đây là một vấn đề mới cần được quan tâm nghiên cứu để lựa chọn ra giải pháp hữu hiệu trong phòng trừ sinh vật gây hại RNM trong khu vực.

\subsection{Bước đầu phân chia lập địa ngập mặn khu vực ven biển Nam Trung Bộ}

Trên cơ sở lựa chọn 7 tiêu chí phân chia lập địa ngập mặn cho khu vực: loại đất ngập mặn, độ mặn nước biển, thời gian phơi bãi, độ thành thục của đất, tỷ lệ phần trăm hạt cát, cao trình đất ngập mặn, hiện trạng rừng và đất ngập mặn, đã xác định được diện tích của từng nhóm dạng lập địa ngập mặn khu vực ven biển Nam Trung Bộ 3 nhóm: khu vực có điều kiện rất thuận lợi, khu vực có điều kiện thuận lợi và khu vực có điều kiện khó khăn. Kết quả tổ hợp các chỉ tiêu phân chia lập địa đã xác định được diện tích một số nhóm lập địa ngập mặn chính cho các địa điểm khu vực Nam Trung Bộ theo bảng sau: 


\section{BÀI BÁO KHOA HỌC}

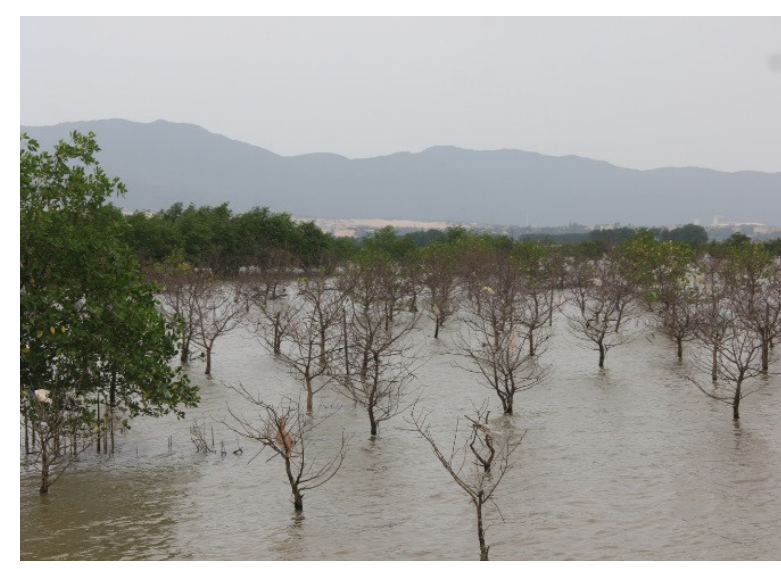

Hình 4. Rùng Bần trắng 10 ha tại tỉnh Bình Định bị chết do loài Giáp xác chân đều (Sphaeroma terebrans) gây hại

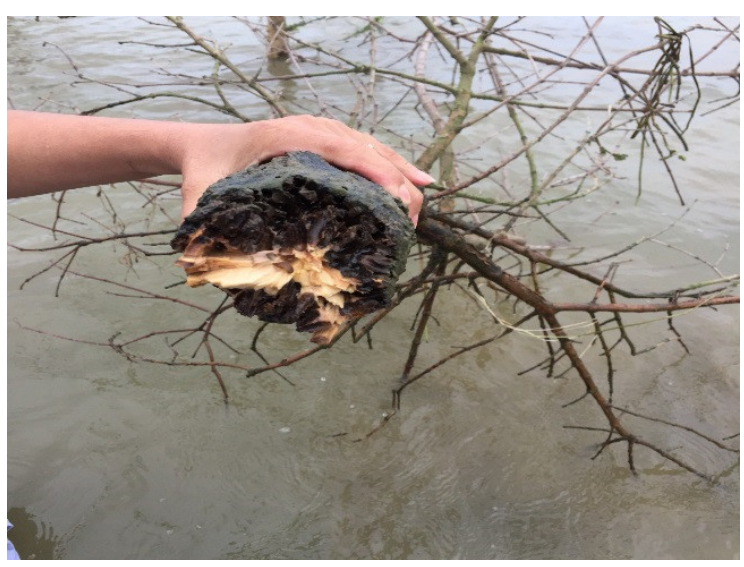

Hình 5. Loài Sphaeroma terebrans hai cây Bần trắng (Sonneratia alba) tại Đầm Thị Nại, tỉnh Bình Định

Bảng 4. Diện tích các nhóm lập địa ngập mặn khu vục Nam Trung Bộ

\begin{tabular}{cccccc}
\hline & Tỉnh & \multicolumn{4}{c}{ Diện tích nhóm lập địa ngập mặn (ha) } \\
\hline STT & & Rất thuận lợi & Thuận lợi & Khó khăn & Cộng \\
\hline 1 & Quảng Nam & 46,02 & 1,75 & 12,45 & 60,22 \\
2 & Quảng Ngãi & 74,36 & 21,06 & 0 & 95,42 \\
3 & Bình Định & 246,97 & 85,05 & 178,99 & 511,01 \\
4 & Khánh Hòa & 43,19 & 11,7 & 1,58 & 56,47 \\
5 & Ninh Thuận & 8,9 & 58,48 & 0,43 & 67,81 \\
6 & Bình Thuận & 10,26 & 14,72 & 8,68 & 33,66 \\
& Cộng & 429,7 & 192,76 & 202,13 & 824,59 \\
\hline
\end{tabular}

Theo kết quả tổng hợp khu vực Nam Trung Bộ có tổng diện tích các nhóm lập địa ngập mặn là 824,59 ha. Trong đó, diện tích nhóm lập địa lập mặn rất thuận lợi có 429,7 ha, diện tích nhóm lập địa thuận lợi 192,76 ha và diện tích lập địa khó khăn 202,13 ha. Tuy nhiên, diện tích đất trống để khôi phục và phát triển RNM tập trung chủ yếu ở 3 tỉnh: Bình Định, Quảng Nam và Ninh Thuận với diện tích rất nhỏ, ở các khu vực khó khăn. Do đó, cần phải áp dụng các giải pháp kỹ thuật lâm sinh như chọn loài, kỹ thuật trồng, chăm sóc kết hợp với các giải pháp về thủy lợi như xây dựng tường mềm giảm sóng, tạo bãi phù hợp sau đó tiến hành trồng và chăm sóc RNM mới có khả năng thành công ở dạng lập địa khó khăn.

\subsection{Giải pháp phục hồi RNM ven biển Nam} Trung Bộ

Từ những nghiên cứu về hiện trạng RNM ở khu vực Nam Trung Bộ, chúng tôi đề xuất các giải pháp trồng rừng phù hợp với các điều kiện lập địa ở khu vực nghiên cứu như sau: 
Bảng 5. Đề xuất giải pháp trồng rùng phù hợp với các điều kiện lập địa ở khu vưc Nam Trung Bộ

\begin{tabular}{|c|c|c|c|c|}
\hline TT & Đặc điểm & \multicolumn{3}{|c|}{ Biện pháp kỹ thuật } \\
\hline I & \multicolumn{4}{|c|}{$\begin{array}{l}\text { Nhóm lập địa I (Rất thuận lợi), dạng bãi triều đang được bồi tụ: Xuất hiện nhờ quá trình vận } \\
\text { chuyển bùn cát tự nhiên đến khu vực bồi tụ, cao trình mặt bãi cao trên } 0,4 \mathrm{~m} \text {, tỷ lệ cát }<50 \% \text {, } \\
\text { thời gian phơi bãi tối thiểu từ } 8 \text { giờ/ngày đêm. }\end{array}$} \\
\hline 1 & Loài cây & \multicolumn{3}{|c|}{ Mắm biển, Đước đôi, Bần trắng } \\
\hline 2 & Cây giống & \multicolumn{3}{|c|}{ Cây con có bầu polyetylen/ quả/ trụ mầm. } \\
\hline & & Mắm biển & Đước đôi & Bần trắng \\
\hline 3 & Tiêu chuẩn cây con & $\begin{array}{l}\text { Tuổi cây: } \geq 6 \text { tháng } \\
D_{\text {oo }}>0,6 \mathrm{~cm} \\
H_{m n}>60 \mathrm{~cm}\end{array}$ & $\begin{array}{l}\text { Tuổi cây: trụ mầm } \\
\text { Chiều dài trụ: > }\end{array}$ & $\begin{array}{l}\text { Tuổi cây: } \geq 6 \text { tháng } \\
D_{\text {oo }}>0,6 \mathrm{~cm}\end{array}$ \\
\hline 4 & Mật độ trồng (cây /ha) & $\geq 3.300$ & $\geq 5.000$ & $\geq 3.300$ \\
\hline 5 & Thời vụ trồng & \multicolumn{3}{|c|}{ Từ tháng 8 đến tháng 10} \\
\hline 6 & Phương thức trồng & \multicolumn{3}{|c|}{ Hỗn giao hoặc thuần loài } \\
\hline 7 & Cải tạo thể nền & \multicolumn{3}{|c|}{$\begin{array}{l}\text { Tỷ lệ cát: }<50 \% \text { không cần cải tạo } \\
\text { Tỷ lệ cát: } \geq 50 \text { cần cải tạo }\end{array}$} \\
\hline 8 & Kỹ thuật hỗ trợ & \multicolumn{3}{|c|}{ Có thể cắm 1 cọc để tăng độ ổn định cho cây trồng } \\
\hline 9 & \multirow{2}{*}{\multicolumn{4}{|c|}{$\begin{array}{l}\text { Công trình phụ trợ } \\
\text { Nhóm lập địa II (Thuận lợi) dạng bãi triều xói mặt: Xuất hiện ở những khu vực vẫn còn đa } \\
\text { RNM có chiều rộng tương đối lớn, bậc xói giữa mặt nền bị xói và đai rừng hiện trạang từ } 0,2 \div \\
0,5 \mathrm{~m} \text {; cao trình bãi khu vực xói lở vần đủ thời gian phơi bãi tối thiểu } 5 \div 6 \text { giờ mồi ngày đêm } \\
\text { cao trình bãi khoảng }-0,2 \div 0,0 \mathrm{~m} \text {. }\end{array}$}} \\
\hline II & & & & \\
\hline 1 & Loài cây & \multicolumn{3}{|c|}{ Mắm biển, Mắm trắng, Đước đôi } \\
\hline 2 & Cây giống & \multicolumn{3}{|c|}{ Cây con có bầu polyetylen } \\
\hline & & Mắm biển & Mắm trắng & Đước đôi \\
\hline 3 & Tiêu chuẩn cây con & $\begin{array}{l}\text { Tuổi cây: } \geq 12 \text { tháng } \\
\text { Doo } \geq 1,2 \mathrm{~cm} \\
H v n \geq 100 \mathrm{~cm}\end{array}$ & $\begin{array}{l}\text { Tuổi cây: } \geq 12 \text { tháng } \\
\text { Doo } \geq 1,2 \\
\operatorname{Hvn} \geq 1,2\end{array}$ & $\begin{array}{l}\text { Tuổi cây: trụ mầm } \\
\text { Chiều dài trụ mầm: } \geq \\
15 \mathrm{~cm}\end{array}$ \\
\hline 4 & Mật độ trồng (cây/ha) & $\geq 3.300$ & $\geq 3.300$ & $\geq 5.000$ \\
\hline 5 & Thời vụ trồng & \multicolumn{3}{|c|}{ Từ tháng 8 đến tháng 10} \\
\hline 6 & Phương thức trồng & \\
\hline 7 & Cải tạo thể nền & \multicolumn{3}{|c|}{$\begin{array}{l}\text { Tỷ lệ cát: }<50 \% \text { không cần cải tạo } \\
\text { Tỷ lệ cát: } \geq 50 \text { cần cải tạo }\end{array}$} \\
\hline 8 & Kỹ thuật hỗ trợ & \multicolumn{3}{|c|}{ Cắm 3 cọc giữ cây } \\
\hline 9 & Công trình phụ trợ & \multicolumn{3}{|c|}{$\begin{array}{l}\text { Phải có công trình tường mềm (kích thước tối thiểu } \mathrm{B}=0,8 \mathrm{~m} \text {; } \\
\mathrm{H}=1,5 \mathrm{~m} \text { ) để tăng khả năng giảm sóng, giảm dòng chảy gây bồi. }\end{array}$} \\
\hline
\end{tabular}

\section{Kết luận}

Trên cơ sở nghiên cứu về hiện trạng RNM Nam Trung Bộ trong bối cảnh biến đổi khí hậu. Viện Sinh thái và Bảo vệ công trình có một số kết luận bước đầu như sau:

- Biến đổi khí hậu và nước biển dâng đã và đang ảnh hưởng trực tiếp đến RNM khu vực Nam Trung Bộ: sẽ có khoảng $9 \%$ dân số vùng ven biển bị ảnh hưởng, diện tích RNM sẽ khó thể tồn tại khi nước biển dâng cuối thế kỷ 21 (dâng từ 78-95cm).

- Đã xác định được 21 loài thực vật, thuộc 12 chi và 10 họ thực vật. Trong đó nhiều loài được ghi nhận tại nhiều khu vực điều tra như Mắm biển (Avicennia marina), Cóc trắng (Lumnitzera racemosa) và Đước đôi (Rhizophora apiculata). Đây là những loài thực vật ngập mặn bản địa sẽ được lựa chọn để khôi phục và phát triển RNM. 


\section{BÀI BÁO KHOA HỌC}

- Đã ghi nhận thêm vùng phân bố mới của loài Cóc đỏ (Lumnitzera littorea (Jack) Voigt) là loài quý hiếm ở mức VU - mức sẽ nguy cấp trong Sách Đỏ Việt Nam (2007) tại Ninh Thuận so với trước đây (Thừa Thiên Huế, Khánh Hòa (Cam Ranh), Bà Rịa-Vũng Tàu (Côn Đảo), Kiên Giang (Phú Quốc), Bạc Liêu).

- Bước đầu đã phát hiện một loài Giáp xác chân đều có tên khoa học là Sphaeroma terebrans Bate, 1866, thuộc họ Sphaeromatideae, bộ Chân đều (Isopoda) hại cây ngập mặn Bần trắng (Sonneratia alba Smith) trên 3 tuổi gây hại RNM ở tỉnh Bình Định.

- Kết quả điều tra đã tổng hợp được diện tích đất quy hoạch cho trồng RNM khu vực Nam Trung Bộ là 824,59 ha. Trong đó, diện tích đất trống ngập mặn là 465,53 ha, diện tích RNM là
359,06 ha. Diện đất trống ngập tập trung chủ yếu ở tỉnh Quảng Nam, Bình Định và Ninh Thuận. Tuy nhiên, diện tích đất này thuộc loại đất ngập mặn có điều kiện khó khăn và rất khó khăn. Do đó, khi triển khai các giải pháp về phục hồi và phát triển $\mathrm{RNM}$ tại các khu vực này cần có các công trình tường mềm giảm sóng, giảm dòng chảy ven bờ để tăng hiệu quả sản phẩm bồi tụ, tăng tỷ lệ thành RNM.

- Bước đầu đề xuất giải pháp trồng RNM phù hợp với đặc điểm lập địa (rất thuận lợi, thuận lợi và khó khăn) bằng giải pháp kỹ thuật lâm sinh. Trong đó, việc lựa chọn loài, tiêu chuẩn cây giống đem trồng, mật độ, phương thức và phương pháp trồng rừng kết hợp với các công trình phù trợ sẽ tăng hiệu quả trồng rừng, tỷ lệ thành rừng.

Lời cám ơn: Nghiên cúu này được sụ hỗ trọ tù nhiệm vu Khoa họ và Công nghệ độc lập cấp Nhà nuớc "Nghiên cứu giải pháp khoa học công nghệ để phục hồi và phát triển RNM ven biển Nam Trung Bộ nhằm ứng phó với biến đổi khi hậu”, mã số BĐKH.19/16-20.

\section{Tài liệu tham khảo}

1. Bộ Nông nghiệp và Phát triển nông thôn (2016), Quyết định số 1819/QĐ-BNN-TCLN ngày 16/5/2017 công bố hiện trạng rùng toàn quốc năm 2016.

2. Bộ Nông nghiệp và Phát triển nông thôn (2018), Quyết định số 1187/QĐ-BNN-TCLN ngày 03/4/2018 về việc công bố hiện trạng rùng toàn quốc năm 2017.

3. Bộ Tài nguyên và Môi trường (2016), Kịch bản biến đổi khi hậu và nuớc biển dâng cho Việt Nam, Nhà xuất bản Tài nguyên Môi trường và Bản đồ Việt Nam, 46-84.

4. Ngô Đình Quế, Nguyễn Xuân Quát (2012), Ứng dụng lập địa trong lâm nghiệp, Nhà xuất bản Nông nghiệp, Hà Nội, 58-60.

5. Nguyễn Xuân Hòa, Phạm Thị Lan, Nguyễn Xuân Trường (2010), Hiện trạng RNM ở dải ven biển Nam Trung Bộ (tù Đà Nẵng đến Ninh Thuận). Tuyển tập nghiên cứu Biển, XVII, 167-177.

6. Hoàng Văn Thơi, Trần Đức Thành, Kiều Mạnh Hà (2012), Nghiên cưu thành phần loài và phân bố cây ngập mặn làm co sở chọn loài cây trồng trên nền san hô ngập nước ven biển, đảo các tỉnh duyên hải Nam Trung Bộ. Tạp chí Khoa học Lâm nghiệp Việt Nam, 3/2012, 75-81.

7. Phan Nguyên Hồng và Hoàng Thị Sản (1984), Kết quả nghiên cứu về hệ thực vật RNM Việt Nam, Tuyển tập hội thảo Quốc gia về hệ sinh thái RNM Việt Nam lần 1, Hà Nội, 68-73. 


\title{
SOME RESULTS OF RESEARCH ON MANGROVE IN SOUTHERN CENTRAL COAST
}

\author{
Do Quy Manh${ }^{1}$, Nguyen Quoc Huy ${ }^{1}$, Le Van Tuat ${ }^{1}$ \\ ${ }^{1}$ Institute of Ecology and Works Protection
}

\begin{abstract}
Mangroves in the South Central region are a typical, multi-functional ecosystem for coastal areas, mangroves in this area play a particularly important role in protecting estuarine, lagoon, bay areas, preventing erosion and landslides, especially protecting the lives and livelihoods of population communities. The study area with high salinity, frequently affected by strong typhoons every year, is a difficult factor for mangrove restoration. The research has applied the integrated and field survey method of 824.59 hectares of soil and mangroves, of which the area of mangroves is 359.06 hectares. The study identified 21 plant species, belonging to 12 genera and 10 plant families. A new distribution area of Lumnitzera littorea (Jack) Voigt) has been recorded as a rare and valuable species at VU - an endangered level in the Vietnam Red Book (2007) in NinhThuan province. Preliminary discovery of a species of Sphaeroma terebrans Bate (1866), Sphaeromatideae family, that harms white-mangrove species Sonneratia alba over 3 years in BinhDinh province. Initially proposing mangrove planting solutions suitable to site characteristics with silvicultural technical solutions.
\end{abstract}

Keywords: Forest status, mangroves, South Central Coast. 